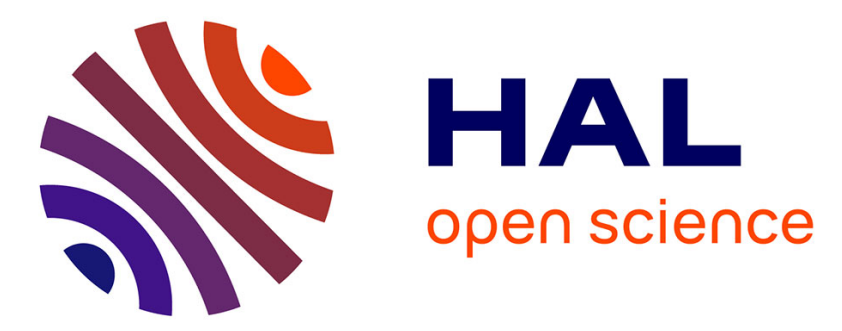

\title{
Biological impacts of local vs. regional land use on a small tributary of the Seine River (France): insights from a food web approach based on stable isotopes
}

N. Hette-Tronquart, T. Oberdorff, E. Tales, Amandine Zahm, J. Belliard

\section{- To cite this version:}

N. Hette-Tronquart, T. Oberdorff, E. Tales, Amandine Zahm, J. Belliard. Biological impacts of local vs. regional land use on a small tributary of the Seine River (France): insights from a food web approach based on stable isotopes. Environmental Science and Pollution Research, 2018, 25 (24), pp.23583-23594. 10.1007/s11356-017-8771-5 . hal-02156552

\section{HAL Id: hal-02156552 \\ https://hal.science/hal-02156552}

Submitted on 14 Jun 2019

HAL is a multi-disciplinary open access archive for the deposit and dissemination of scientific research documents, whether they are published or not. The documents may come from teaching and research institutions in France or abroad, or from public or private research centers.
L'archive ouverte pluridisciplinaire HAL, est destinée au dépôt et à la diffusion de documents scientifiques de niveau recherche, publiés ou non, émanant des établissements d'enseignement et de recherche français ou étrangers, des laboratoires publics ou privés. 


\title{
Biological impacts of local vs. regional land use on a small tributary of the Seine River (France): insights from a food web approach based on stable isotopes
}

\author{
Nicolas Hette-Tronquart ${ }^{1}$. Thierry Oberdorff ${ }^{2}$ - Evelyne Tales ${ }^{1} \cdot$ Amandine Zahm $^{1}$. \\ Jérôme Belliard ${ }^{1}$
}

Received: 19 September 2016 / Accepted: 8 March 2017 /Published online: 23 March 2017

(C) Springer-Verlag Berlin Heidelberg 2017

\begin{abstract}
As part of the landscape, streams are influenced by land use. Here, we contributed to the understanding of the biological impacts of land use on streams, investigating how landscape effects vary with spatial scales (local vs. regional). We adopted a food web approach integrating both biological structure and functioning, to focus on the overall effect of land use on stream biocœnosis. We selected 17 sites of a small tributary of the Seine River (France) for their contrasted land use, and conducted a natural experiment by sampling three organic matter sources, three macroinvertebrate taxa, and most of the fish community. Using stable isotope analysis, we calculated three food web metrics evaluating two major dimensions of the trophic diversity displayed by the fish community: (i) the diversity of exploited resources and (ii) the trophic level richness. The idea was to examine whether (1) land-use effects varied according to spatial scales, (2) land use affected food webs through an effect on community structure and (3) land use affected food webs through an effect on available resources. Beside an increase in trophic diversity from upstream to downstream, our empirical data showed that food webs were influenced by land use in the riparian
\end{abstract}

Responsible editor: Philippe Garrigues

Electronic supplementary material The online version of this article (doi:10.1007/s11356-017-8771-5) contains supplementary material, which is available to authorized users.

Nicolas Hette-Tronquart

nicolas.hette@edu.mnhn.fr

1 Irstea, UR HBAN, 1 rue Pierre-Gilles de Gennes, CS 10030, F-92761 Antony, France

2 UMR 5174 EDB (Laboratoire Evolution et Diversité Biologique), CNRS, IRD, UPS, ENFA, Université Paul Sabatier,

F-31062 Toulouse, France corridors (local scale). The effect was complex, and depended on site's position along the upstream-downstream gradient. By contrast, land use in the catchment (regional scale) did not influence stream biocœnosis. At the local scale, community structure was weakly influenced by land use, and thus played a minor role in explaining food web modifications. Our results suggested that the amount of available resources at the base of the food web was partly responsible for food web modifications. In addition, changes in biological functioning (i.e. feeding interactions) can also explain another part of the land-use effect. These results highlight the role played by the riparian corridors as a buffer zone, and advocate that riparian corridor should be at the centre of water management attention.

Keywords Trophic diversity · Food webs $\cdot$ Stable isotopes . Land use $\cdot$ Fish community $\cdot$ Biological functioning $\cdot$ Stream ecology $\cdot$ Urbanisation

\section{Introduction}

Streams are closely connected to the surrounding terrestrial landscape (Hynes 1975). As such, streams display numerous features that are influenced by the structure of the landscape mosaic (see Allan 2004 for a review). Some features are affected by the direct surrounding land use (for example, degree of shading, or abundance of woody debris, influenced by riparian vegetation, Sweeney 1992), while others rely on the land use at larger spatial extent (e.g. water inputs, sediment load, or channel form depending on erosion, Allan et al. 1997). Thus, it is necessary to consider at least two spatial scales (local vs. regional) when addressing the effect of land use on stream ecosystems. In addition, the understanding of 
the interplay between both scales gives valuable information that could help setting priorities in terms of stream management.

According to previous studies, land use affects both structure (by determining patterns of species distribution, Argent and Carline 2004; Maloney and Weller 2011) and functioning (i.e. the interactions among species, or between species and physical habitat, e.g. Martinez et al. 2016) of biological communities. However, rare are studies that synthetically measure the effects of land use by integrating both structural and functional aspects (but see di Lascio et al. 2013). Such studies are promising, because integrative measurements could serve as early warnings of ecosystem disturbance, and could detect perturbations earlier than classical indicators that only focus on one aspect (Young and Collier 2009, Crane et al. 2011, Bentivoglio et al. 2015). One objective of this study is to use such an integrative measurement to assess the biological impacts of land use on streams. To this end, food webs, as networks of trophic interactions, are ideal candidates that "reconcile the structure and function of biodiversity" (Thompson et al. 2012) because they integrate both community composition (related to structure) and interactions within the community (related to functioning).

Several methods can be used to assess food webs. For example, the use of stable isotope analyses (Boecklen et al. 2011), combined with the developments of isotopic metrics (Layman et al. 2007, Jackson et al. 2011), offers the possibility to quantitatively characterise food webs. We preferred stable isotopes to gut content analyses because the isotope signals integrate the feeding interactions over space and time (Rasmussen et al. 2009, Vander Zanden and Rasmussen 1999), whereas gut contents are at best a snapshot of what an individual has ingested but not necessarily assimilated (Michener and Lajtha 2007). In addition, stable isotopes can be useful for determining the sources of organic matter used by food webs (e.g. Middelburg 2014).

In this study, we adopted a food web approach based on stable isotopes to investigate the biological effects of land use at both local and regional scales. Based on results of previous studies (e.g. Allan 2004; Marzin et al. 2013), we expected that both local and regional scales are necessary to describe land use influence on food webs. At the local scale, we anticipated that land use will mainly influence food webs via instream habitat modifications (Sweeney and Czapka 2004) and/or allochthonous organic matter inputs (Woodward and Hildrew 2002). For instance, land drainage or flood management in the case of urban development or agricultural practises often lead to river channelisation, deepening or straightening that further generate loss of instream habitat diversity (Hladyz et al. 2011). In addition, riparian clearing alters instream primary production by affecting the degree of shading (Quinn et al. 1997), and reduces allochthonous inputs of organic matter (Scarsbrook et al. 2001). At the regional scale, we expected that land use will have an effect on food webs mainly through water quality, because urban and agricultural land, unlike forested land (Bott et al. 2006), are often associated with excessive loads of sediments, nutrients (Anderson and Cabana 2005, Moog and Whiting 2002), pesticides and other pollutants (Feld et al. 2011, Friberg et al. 2011). Supplementary to land use, we expected that food webs varied from upstream to downstream, as demonstrated by previous studies (e.g. HetteTronquart et al. 2016), and we took this effect into account to examine the potential effect of land use. We also considered the potential alteration of food webs due to water quality, because this effect could also explain part of the supposed biological impact of land use.

To quantify the influence of land use on food webs, we selected 17 sites within the catchment of the Orge River, a small tributary of the Seine River, and focused on fish communities. We used fish communities because it is very difficult to sample 17 whole food webs, and because fish food web at least partly integrates what happens at the lower trophic level (e.g. trophic contamination transfer, Pouilly et al. 2013). Thus, it provides a substantial part of the whole stream food web. Using fish stable isotope signals, we determined three isotopic metrics (i.e. ISA, $\mathrm{CR}_{\mathrm{adp}}$ and $\mathrm{NR}_{\mathrm{adp}}$ ) focusing on two major dimensions of food webs: the diversity of exploited resources and the trophic level richness. We then used the three metrics to evaluate the biological impacts of land use, and completed our food web analysis by estimating the effect of land use on biological structure and the isotopic variability of basal resources. By doing so, the goal was to address the three following issues: (i) How does the land-use effect on stream food webs vary with spatial scales (local vs. regional scales)? (ii) Does land use necessarily influence food webs through an effect on community structure (i.e. community composition or species richness)? and (iii) Among the other potential effects of land use, do the modifications in available resources in turn affect food webs?

\section{Materials and methods}

As a preliminary remark, all calculations and statistical analyses were performed using the $\mathrm{R}$ software version 3.2.1 ( $\mathrm{R}$ core team, 2015).

\section{Site sampling and stable isotope data}

The Orge River $\left(937 \mathrm{~km}^{2}\right.$, mean annual discharge $\left.4 \mathrm{~m}^{3} \cdot \mathrm{s}^{-1}\right)$ is a relatively small tributary of the Seine River (France), located between the coordinates $1^{\circ} 24^{\prime} 25^{\prime \prime}-1^{\circ} 48^{\prime} 46^{\prime \prime} \mathrm{E}$ and $48^{\circ} 26^{\prime}$ $47^{\prime \prime}-48^{\circ} 46^{\prime} 27^{\prime \prime} \mathrm{N}$. We selected the Orge River, because the catchment displayed various types of land use, while its relatively small size makes sure that the whole catchment is subjected to similar climatic conditions and geology. Overall, the 
Orge River landscape is dominated by agricultural land representing $49 \%$ of the whole catchment area. Upstream parts of the catchment are mostly associated with forested land ( $28 \%$ of the whole catchment), but subjected to wastewater treatment plant discharges, while downstream areas are generally associated with urban land $(23 \%$ of the whole catchment), but free of any wastewater treatment plant discharge (see Fig. 1). As a result, the level of anthropogenic pressures across the catchment is pervasive and evaluated between moderate to high, as reflected by the scores of the French fish biotic index (Oberdorff et al. 2002). Within this context, we selected 17 sites displaying contrasted land use at both local and regional scales (see Fig. 1 and Online Resource 1). Sampling occurred once, during the summer of 2009 (see Online Resource 1 for more details on sampling), and was conducted with two goals: (1) to assess the biological impact of land use on the river focusing on the fish food web and (2) to gather additional information about other parts of the river food web using selected basal resources and macroinvertebrates. Sampling of the fish community was comprehensive, generally discarding only rare species (defined as species with only one-three small individuals). The sampling of the basal resources focused on three types of resources to encompass most part of the natural range in resources: leaf litter stood for local allochthonous matter, epilithic biofilm for local autochthonous production and suspended matter for a mixture of organic/inorganic material drifting from upstream. Last, three target taxa of macroinvertebrates (Baetidae, Gammaridae and Sphaeriidae) were sampled to assess the stable isotope baseline of our sites as recommended by Anderson and Cabana (2007). Stable isotope analyses of the 976 collected samples were conducted following Hette-Tronquart et al. (2016). Raw isotope ratios were corrected following recommendations of Werner and Brand (2001; blank-, drift-, linearity- and standard-corrections). In addition, fish isotope ratios that were obtained from fin clips were transformed using equations described in Hette-Tronquart et al. (2012) to reflect isotope signals of muscle tissues.

\section{Isotopic metrics}

We evaluated the biological impacts of land use focusing on two major dimensions of the trophic diversity displayed by the fish community: (1) the diversity of the exploited resources and (2) the trophic level richness. Given the strong link between the isotopic space $\left(\delta^{13} \mathrm{C}-\delta^{15} \mathrm{~N}\right.$ biplot $)$ and the trophic space (Newsome et al. 2007; Semmens et al. 2009; Jackson et al. 2011), we used stable isotopes to quantify the trophic diversity, and calculated three isotopic metrics ISA (isotopic space area), $\mathrm{CR}_{\mathrm{adp}}$ and $\mathrm{NR}_{\mathrm{adp}}$ ("adapted" carbon and nitrogen ranges). Derived from the original Layman's metrics TA, CR and NR, (Layman et al. 2007), the adaptations mainly consisted in considering a standard ellipse for each species before the convex hull's determination, and integrated a Bayesian approach. ISA (derived from TA) integrates both dimensions of trophic diversity, and could be interpreted as a measurement of trophic diversity, while $\mathrm{CR}_{\text {adp }}$ and $\mathrm{NR}_{\text {adp }}$ (like CR and NR) each focuses on one dimension, the diversity of the exploited resources and the trophic level richness, respectively.

We preferred using these "adapted" metrics, because they were mathematically defined for all types of community (including communities with less than three species) contrarily to the original metrics. At the same time, our metrics used a Bayesian approach that was first developed to determine the isotopic niche of species (Jackson et al. 2011). Consequently, they were less sensitive to the number of individuals present in the community compared to the original metrics (Syväranta et al. 2013).

To calculate the metrics, we first determined the representation of each fish community ( 1 site $=1$ community) in the isotopic space $\left(\delta^{13} \mathrm{C}-\delta^{15} \mathrm{~N}\right.$ biplot $)$, using the stable isotope signals of fish individuals. Each community representation (see a theoretical example on Fig. 2) combined standard ellipses (one per species with at least three individuals), and point isotope signals in six cases where a standard ellipse could not be calculated. Using the Bayesian approach developed in the SIBER R package (Jackson et al. 2011), we obtained 4000 representations of each community, based on 4000 different estimations of the species standard ellipses (see our R-script for the calculations in Online Resource 2).

From each representation, we calculated the three isotopic metrics (ISA, $\mathrm{CR}_{\mathrm{adp}}$ and $\mathrm{NR}_{\mathrm{adp}}$ ). ISA was equal to the area of the convex hull encompassing the standard ellipses and point signals (see the theoretical example of Fig. 2). $\mathrm{CR}_{\mathrm{adp}}$ and $\mathrm{NR}_{\text {adp }}$ were defined as the range of $\delta^{13} \mathrm{C}$ and $\delta^{15} \mathrm{~N}$ signals displayed by the community representation, respectively (see Fig. 2). Using the Bayesian approach, we obtained a distribution of 4000 values per metric (one value for each community representation) and for the analyses we considered the mean of each distribution.

\section{Land use}

Land use at each scale (local and regional) was described by a multivariate index combining the relative proportions of three main types of land use (i.e. forested, agricultural and urban lands). For the local scale, proportions were estimated as percentages of the total area of a buffer (two 100-m wide strips that extended $2 \mathrm{~km}$ upstream the sampling site on both side of the stream), while for the regional scale, proportions were expressed as percentages of the upstream catchment area. For both scales, land covers were calculated using data from the regional geographic information system of the "Institut d'Aménagement et d'Urbanisme d'île-de-France" (land cover: 2003, precision level: $25 \times 25 \mathrm{~m}^{2}, 48$ land use categories, 


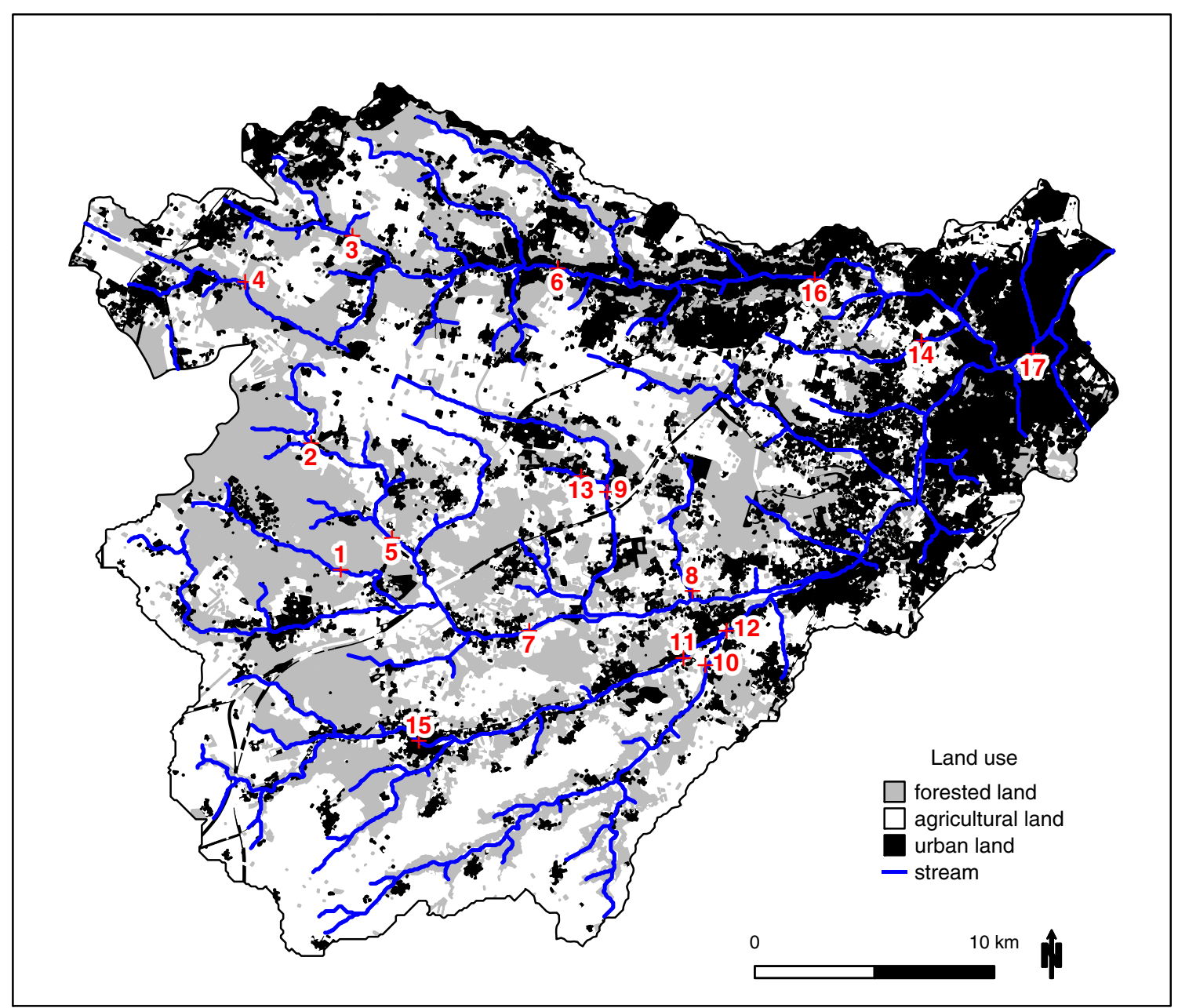

Fig. 1 Distribution of the 17 sites across the Orge River catchment

see Online Resource 3 for the category codification, exclusion of water bodies representing less than $0.7 \%$ of the Orge River catchment), and were obtained by summing up the percentages of surface covered by the categories (1 to 3), (4 to 8, 10 and 13) and (11, 12 and 14 to 48), for forested, agricultural and urban land, respectively. Because these proportions were highly interdependent, we summarised land use information for each scale using the first axis of a principal component analysis, after applying the arcsine squared root transformation on the percentages to improve normality. We kept only the first axes because they both explained most of the total variance (75 and $77 \%$, at local and regional scales, respectively). The first axes then served as two predictor variables describing Land Use at Local scale (LUL) and Land Use at Regional scale (LUR, see Fig. 3). At the local scale, LUL was correlated to both forested and urban lands (Pearson's correlation test, $p$ values $<0.001$, cor $=-0.87$ and 0.99 , respectively), and thus described a land use gradient from sites whose buffer zone was mostly covered with forested land, to sites where urban land predominated in the buffer zone. Consequently, we interpreted LUL effect mostly as an effect of urbanisation in the buffer zone. At the regional scale, LUR was correlated to forested and agricultural lands (Pearson's correlation test, $p$ values $<0.001$, cor $=-1.00$ and 0.87 , respectively), and thus described the decrease in forested land areas in the catchment as opposed to the increase in agricultural land. As a result, LUR effect was interpreted as the presence of forested land in the catchment.

\section{Other variables}

In addition to land use, we considered two other potential determinants of food webs: upstream-downstream gradient (UDG) and water quality (WQ). Food webs are known to change from upstream to downstream (Chang et al. 2012, Hette-Tronquart et al. 2016), and we had to take this effect into account to examine the potential effect of land use because our sites covered most part of the upstream-downstream gradient of the Orge River. Petts and Calow (1996) defined the upstream-downstream gradient as a progressive longitudinal change in several physical features of rivers, thus we took into account 6 


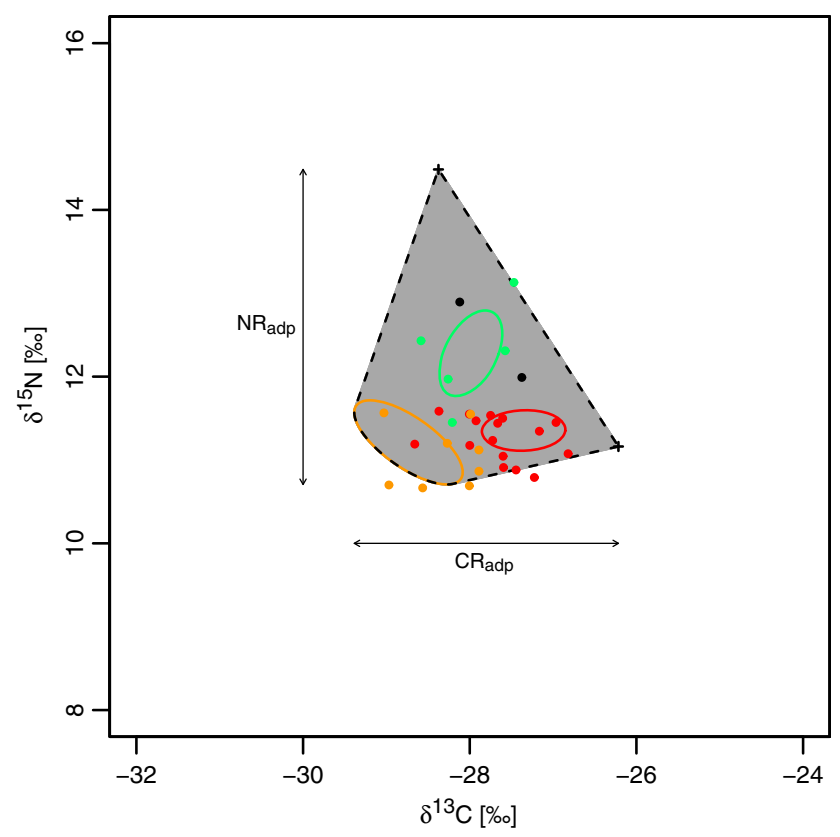

Fig. 2 Theoretical example of community representation in the $\delta^{13} \mathrm{C}$ $\delta^{15} \mathrm{~N}$ biplot and of isotopic metric calculation. Points are fish individuals. In this example, there were three species displaying at least three individuals (green, red and orange) for which standard ellipses could be estimated. There were also four individuals from four species for which we could not estimate a standard ellipse. The two black points were well within the community, whereas the two black crosses are extreme individuals that were essential for community representation. Then, the isotopic space area (ISA) was the area of the convex hull that encompassed the standard ellipses and the two extreme individuals (grey area). The range in carbon $\left(\mathrm{CR}_{\mathrm{adp}}\right)$ and nitrogen $\left(\mathrm{NR}_{\mathrm{adp}}\right)$, was the projection of this area on the $x$-axis and $y$-axis, respectively

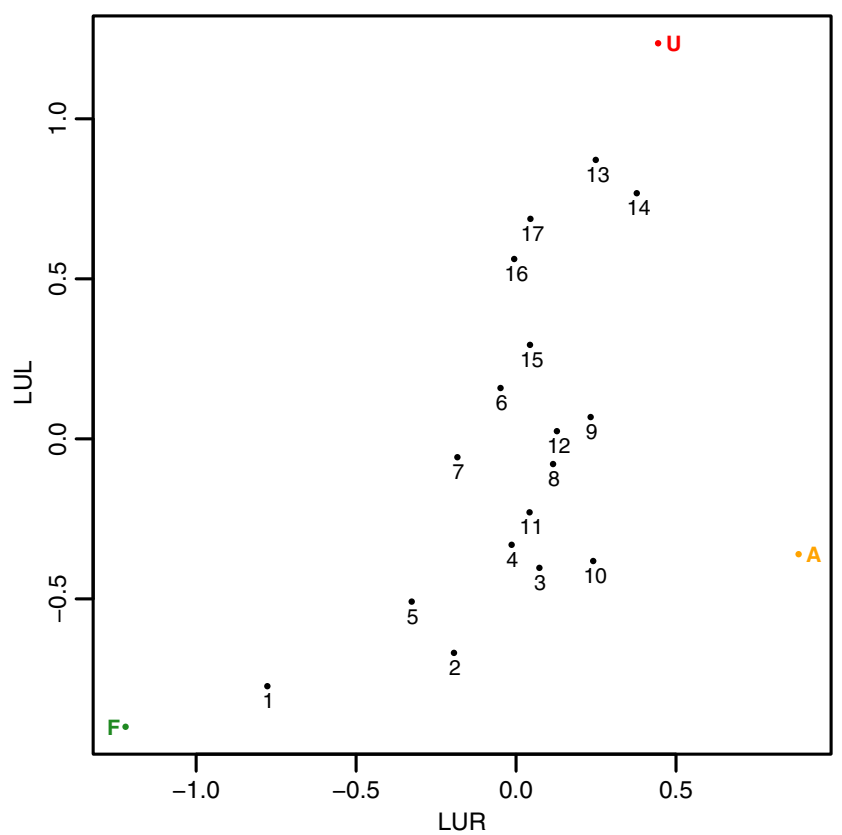

Fig. 3 Site distribution across both land-use gradients (local: LUL and regional: LUR). To specify the meaning of LUL and LUR, three extreme land-use patterns are plotted along with the 17 sites. F (green), A (orange), $U($ red $)=$ potential site with $100 \%$ forested, agricultural or urban land, respectively, at both the local and regional scales changing physiographic data (i.e. stream flow, mean depth, mean width, mean slope, distance from the source and catchment area upstream of the site) to estimate the position of our 17 sites along this gradient. We summarised the highly correlated variables by performing a principal component analysis on their log-transformed values, and kept only the first axis that explained most of the total variance $(83 \%)$. We called this multivariate index UDG, and used it as a supplementary predictor variable. UDG was highly correlated to each of the physiographic data (Pearson's correlation test, $p$ values $<0.002$, cor $>0.80$ for all data except for mean slope, cor $=-0.69$ ), but described the upstream-downstream gradient more finely than each variable alone.

Water quality could also influence food webs (e.g. Guilpart et al. 2012), and is widely affected by land use (Allan 2004). As a result, we wanted to examine whether the potential land-use effect on food web was related to water quality. To do so, we computed data on nutrient load (concentrations in nitrate, ammonium, phosphate and total inorganic phosphorous), organic matter (concentrations in suspended matter, in the labile, semi-labile and refractory parts of dissolved, particulate and benthic organic matter, in oxygen) and microbial contamination (concentration in coliform bacteria), using annual mean values from the Riverstrahler model (Ruelland et al. 2007). The data were log-transformed for normality, and summarised using a principal component analysis to obtain a general picture of water quality. From the analysis, we kept the first two axes, explaining 46 and $27 \%$ of the total variance, respectively. The resulting multivariate indices WQ1 and WQ2 were then used as predictor variables. Correlations between WQ1 and WQ2 and the original variables are given in Table 1 . WQ1 clearly represented a pollution gradient that opposed oxygen concentration to the other parameters (nutrient concentrations, suspended matter, organic matter and coliform bacteria concentration), while WQ2 was associated with variables (e.g. concentrations in suspended matter, phosphate) that generally result from large-scale processes such as erosion, or nutrient retention (cf. Allan et al. 1997).

Last, we investigated whether changes in biological structure could explain the potential effect of land use on food webs, focusing on fish community composition and species richness. For each site, fish community composition was described using species relative abundance (Hellinger transformation, Borcard et al. 2011), and species richness was calculated as the number of present fish species.

\section{Data analysis}

Overall, we considered five explanatory variables: two related to land use (LUL and LUR), one related to the 
Table 1 Correlations (Pearson's test) between the two first axes of the principal component analysis (WQ1 and WQ2), and the original data describing water quality. Original data are concentrations

\begin{tabular}{|c|c|c|c|c|}
\hline \multirow[t]{2}{*}{ Pearson's test } & \multicolumn{2}{|l|}{ WQ1 } & \multicolumn{2}{|l|}{ WQ2 } \\
\hline & $p$ value & cor & $p$ value & cor \\
\hline Nitrate & $<0.001$ & 0.74 & n.s. & n.s. \\
\hline Ammonium & $<0.001$ & 0.86 & n.s. & n.s. \\
\hline Phosphate & n.s. & n.s. & 0.001 & -0.72 \\
\hline Total inorganic phosphorous & 0.050 & 0.48 & 0.004 & -0.66 \\
\hline Suspended matter & n.s. & n.s. & $<0.001$ & 0.82 \\
\hline $\mathrm{DOM}_{1}$ & $<0.001$ & 0.74 & n.s. & n.s. \\
\hline $\mathrm{DOM}_{2}$ & 0.004 & 0.67 & 0.002 & -0.69 \\
\hline $\mathrm{DOM}_{3}$ & 0.005 & 0.64 & 0.033 & -0.52 \\
\hline $\mathrm{POM}_{1}$ & $<0.001$ & 0.78 & 0.038 & 0.51 \\
\hline $\mathrm{POM}_{2}$ & $<0.001$ & 0.77 & 0.029 & 0.53 \\
\hline $\mathrm{POM}_{3}$ & 0.010 & 0.60 & $<0.001$ & 0.77 \\
\hline $\mathrm{BOM}_{1}$ & $<0.001$ & 0.93 & n.s. & n.s. \\
\hline $\mathrm{BOM}_{2}$ & $<0.001$ & 0.93 & n.s. & n.s. \\
\hline $\mathrm{BOM}_{3}$ & 0.009 & 0.61 & 0.040 & 0.50 \\
\hline Oxygen & 0.050 & -0.48 & n.s. & n.s. \\
\hline Coliform bacteria & $<0.001$ & 0.74 & 0.028 & -0.53 \\
\hline
\end{tabular}

$D O M_{i}$ concentration in dissolved; $P O M_{i}$ concentration in particulate; $B O M_{i}$ concentration in benthic organic matter; $i 1=$ labile, $2=$ semi-labile and 3 = refractory; n.s. non-significant test

upstream-downstream gradient (UDG) and two related to water quality (WQ1 and WQ2). Using a Spearman correlation test and calculating variance inflation factors, we first examined the relationships among the five explanatory variables.

Then, we investigated the effects of these explanatory variables on the fish food web of our sites. We used generalised linear models (GLM, Gaussian family and variance, link function $=$ identity) to relate the patterns of the isotopic metrics (ISA, $\mathrm{CR}_{\mathrm{adp}}$ and $\mathrm{NR}_{\mathrm{adp}}$ ) with the explanatory variables, including quadratic terms and interactions between LUL or LUR and each of the other variables. Significant interaction terms indicated that the land use effects were continuously changing along the upstream-downstream or the water quality gradients. Concerned for model parsimony, we determined significant variables using both forward and backward selections displayed by the ordistep function of the vegan $\mathrm{R}$ package (Oksanen et al. 2015).

Last, we tested the effects of the explanatory variables on biological structure, described by community composition and species richness. In the case of community composition, we conducted a redundancy analysis to explore the patterns of fish taxonomic composition that were explained by a linear combination of the explanatory variables. "Conceptually, redundancy analysis is a multivariate (meaning multi-response) multiple linear regression followed by a principal component analysis of the table of fitted values" (Borcard et al. 2011). Concerning species richness, we followed the same approach than for the isotopic metrics, and used generalised linear models.

In addition, we conducted supplementary analyses on the isotope signals of resources and macroinvertebrates to investigate whether the potential effect of land use on fish food web could be associated with a change in food web resources like in Docile et al. (2016). In particular, we examined whether the stable isotope baseline of our sites (mean $\delta^{15} \mathrm{~N}$ signals of Baetidae, Sphaeriidae and Gammaridae), and the isotope signal variability of the resources (range in $\delta^{13} \mathrm{C}, \delta^{15} \mathrm{~N}$ signals, respectively, among leaf litter, epilithic biofilm, and suspended matter) were related to land use, according to linear models.

\section{Results}

\section{Correlations among explanatory variables}

Land uses at local (LUL) and regional (LUR) scales were moderately correlated (Spearman's correlation test, rho $=0.57, p=0.019, S=352$ ). As shown by the "U"-point in Fig. 3, a high amount of urban land in the catchment area was associated with a high amount of urban land in the buffer zone. Similarly, the "F"-point indicated that the dominance of forested land at local scale mirrored the same pattern at regional scale. At the local scale, land use (LUL) was correlated to water pollution (WQ1, Spearman's correlation test, rho $=0.62, p=0.010, S=312$ ), reflecting that the increase in urbanisation at local scale was associated with an increase in water pollution. At the regional scale, land use (LUR) was strongly correlated with water quality 2 (WQ2, Spearman's correlation test, rho $=0.79, p<0.001, S=168$ ), suggesting that a decrease in forested land in the catchment area was associated with an increase in erosion. Although other correlations among the variables were not significant, the three observed correlations could potentially cause collinearity issues in the analysis. However, variance inflation factors among the five variables were always smaller than 3 , and indicated that the linearity dependencies among variables could not bias our results (Borcard et al. 2011).

\section{Isotopic metrics}

The isotopic space area (ISA) and the carbon range $\left(\mathrm{CR}_{\mathrm{adp}}\right)$ were influenced by land use but only at the local scale. Both metrics were best explained by a model including UDG and a negative interaction between UDG and LUL (Fig. 4, $p$ value $=0.022 / 0.003$, adjusted $R^{2}=0.34 / 0.51$ for ISA $/ \mathrm{CR}_{\mathrm{adp}}$, respectively, Table 2 ). In other words, the trophic diversity 


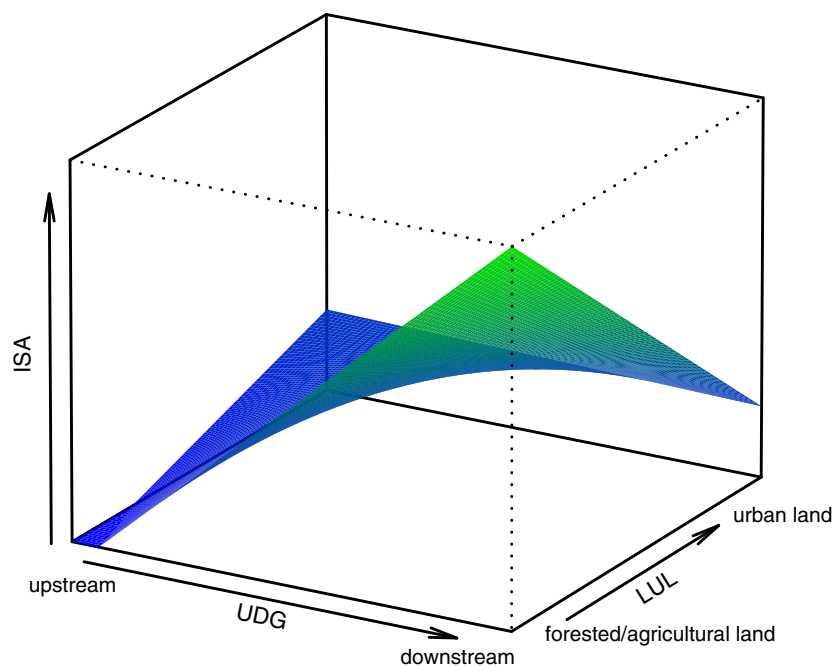

Fig. 4 Representation of the generalised linear model including UDG and a negative interaction between UDG and LUL. We found similar models for the isotopic space area (ISA) and the range in carbon $\left(\mathrm{CR}_{\mathrm{adp}}\right)$. Thus, we displayed only the modelled relationship for ISA, as an example

and the heterogeneity in exploited resources (assessed by ISA and $\mathrm{CR}_{\text {adp }}$, respectively) increased from upstream to downstream. In addition, the interaction reflected that headwater streams (UDG < 0) displayed increasing trophic diversity and heterogeneity in exploited resources when the relative proportion of urban land increased at local scale, while the reverse pattern was found for more downstream sites (UDG > 0). By contrast, the best model for nitrogen range $\left(\mathrm{NR}_{\text {adp }}\right)$ only included UDG (Fig. 5, $p$ value $=0.012$, adjusted $R^{2}=0.31$ ), indicating that the trophic level richness increased from upstream to downstream but was not influenced by land use. Note that land use at the regional scale (LUR) and water quality (both WQ1 and WQ2) were never significantly related to the isotopic metrics.

\section{Biological structure}

Sixteen percent of the variability in the fish community composition could be explained by a linear model combining UDG and LUL (redundancy analysis, adjusted

Table 2 Statistical details of the models (GLM) explaining the isotopic space area (ISA) and the range in carbon $\left(\mathrm{CR}_{\mathrm{adp}}\right)$. The models were very similar and included UDG and a negative interaction between UDG and LUL (abbreviated UDG:LUL)

\begin{tabular}{|c|c|c|c|c|c|c|}
\hline \multirow[t]{2}{*}{ Coefficients } & \multicolumn{2}{|c|}{ Estimate } & \multicolumn{2}{|c|}{$\mathrm{t}$-value } & \multicolumn{2}{|l|}{$p$-value } \\
\hline & ISA & $\mathrm{CR}_{\mathrm{adp}}$ & ISA & $\mathrm{CR}_{\mathrm{adp}}$ & ISA & $\mathrm{CR}_{\mathrm{adp}}$ \\
\hline Intercept & 5.7 & 3.0 & 8.2 & 16.4 & $<0.001$ & $<0.001$ \\
\hline UDG & 1.6 & 0.5 & 3.2 & 3.9 & 0.007 & 0.002 \\
\hline UDG:LUL & -1.9 & -0.9 & -2.5 & -4.2 & 0.028 & $<0.001$ \\
\hline
\end{tabular}

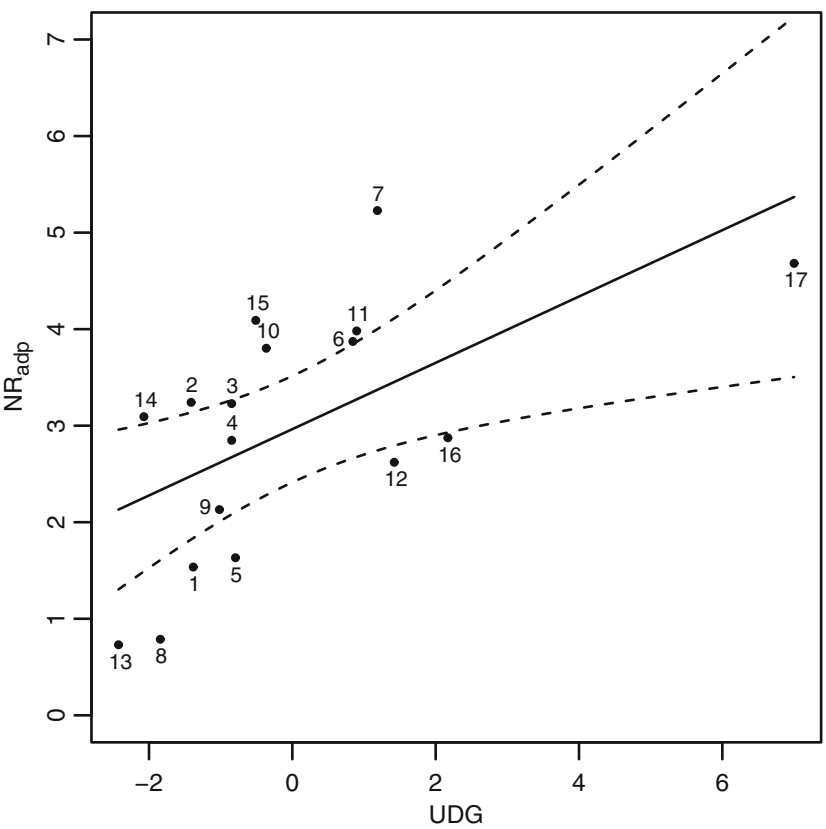

Fig. 5 Relationship between the range in nitrogen $\left(\mathrm{NR}_{\mathrm{adp}}\right)$ and UDG. Sites are presented by the numbered points and the linear model is given by the solid line

$R^{2}=0.16$; permutation $F$ test, $p=0.001, F=2.58$; Fig. 6a). The first axis of the analysis explained most of the variation $(62 \%)$ and was correlated to UDG (cor $=-0.97)$. The second axis explained $38 \%$ of the constrained variance and was correlated to LUL $($ cor $=1.00)$. Downstream sites were associated with Rutilus rutilus and Gobio gobio, whereas upstream sites were associated with Gasterosteus gymnurus. Concerning land-use effect, sites displaying high proportion of urban land in the buffer zone seemed characterised by a high abundance of G. gymnurus. On the contrary, sites whose buffer zone was highly covered by forested land were related to Cottus gobio.

In addition, species richness was significantly related to UDG, WQ1 and an interaction term between UDG and WQ1 ( $p$ value $<0.001$, adjusted $R^{2}=0.86$ ). Species richness increased from upstream to downstream (Fig. 6b) but tended to decrease when water pollution increased (Table 3). The negative interaction between UDG and WQ1 indicated that species richness tended to increase with increasing water pollution at the most upstream sites (UDG $<-1.3$ ), while the reverse pattern was found for more downstream sites (UDG $>-1.3$ ).

\section{Stable isotope signals of basal resources and macroinvertebrates}

We did not find significant differences in $\delta^{15} \mathrm{~N}$ signals among Baetidae, Sphaeriidae and Gammaridae (KruskalWallis rank sum test, $p$ value $=0.110, \chi^{2}=4.42$ ). Thus, 


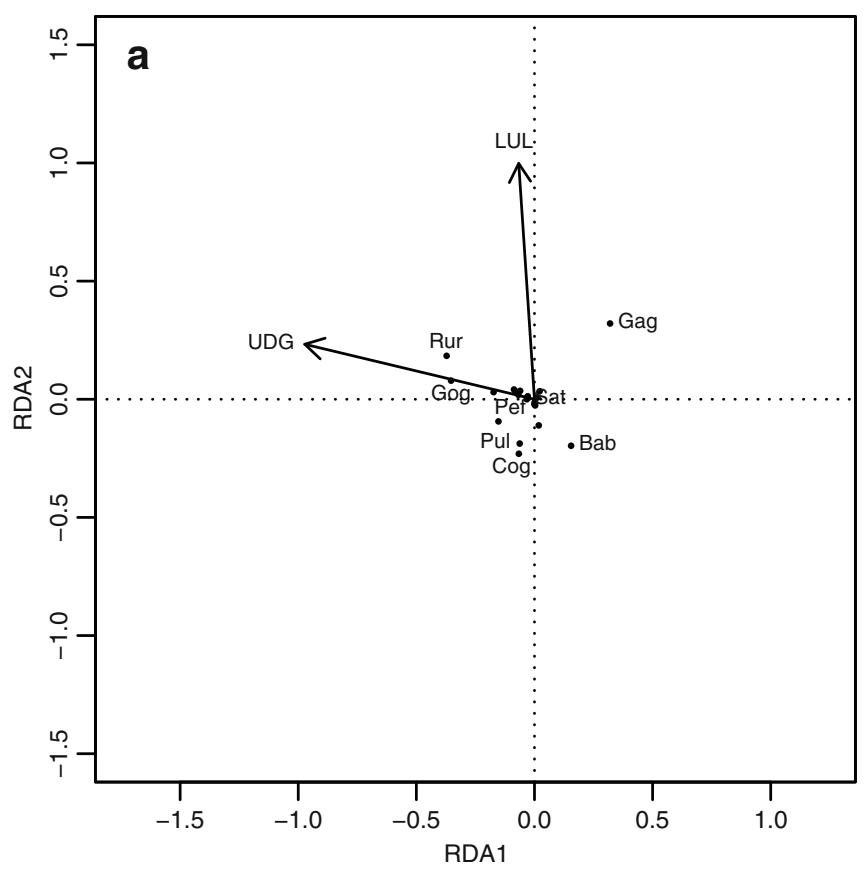

Fig. 6 Effect of land-use on the biological structure (a: community composition, b: species richness). a Biplot from the redundancy analysis using two variables (UDG and LUL). Arrow length corresponds to the strength of the relationships among variables and axes. Points indicate species score on the RDA axes. Three letter codes indicate peculiar species: Bab (Barbatula barbatula), Cog (Cottus gobio),

we decided to estimate the isotope baseline of our sites by aggregating the mean $\delta^{15} \mathrm{~N}$ signals of these three taxa. The resulting baseline was not significantly related to any of the explanatory variables (LUL, LUR, UDG, WQ1 or WQ2).

The isotope variability among resources (leaf litter, epilithic biofilm and suspended matter) was related to different variables depending on the signals $\left(\delta^{13} \mathrm{C}\right.$ or $\left.\delta^{15} \mathrm{~N}\right)$. For carbon, the variability increased from upstream to downstream ( $p$ value $<0.001$, adjusted $R^{2}=0.55$, Fig. 7), while for nitrogen, the variability was best related to the negative interaction between WQ1 and LUL ( $p$ value $<0.001$, adjusted $R^{2}=0.64$, Fig. 8 ). Sites with low water pollution (WQ1 $<0$ ) displayed an increasing variability in $\delta^{15} \mathrm{~N}$ when the relative proportion of urban land

Table 3 Statistical details of the best model (GLM) explaining species richness. The model included UDG, WQ1 and a negative interaction between UDG and WQ1 (abbreviated UDG:WQ1)

\begin{tabular}{llll}
\hline Coefficients & Estimate & $t$ value & $p$ value \\
\hline Intercept & 5.9 & 18.1 & $<0.001$ \\
UDG & 1.8 & 8.0 & $<0.001$ \\
WQ1 & -0.4 & -2.4 & 0.034 \\
UDG:WQ1 & -0.3 & -2.4 & 0.030 \\
\hline
\end{tabular}

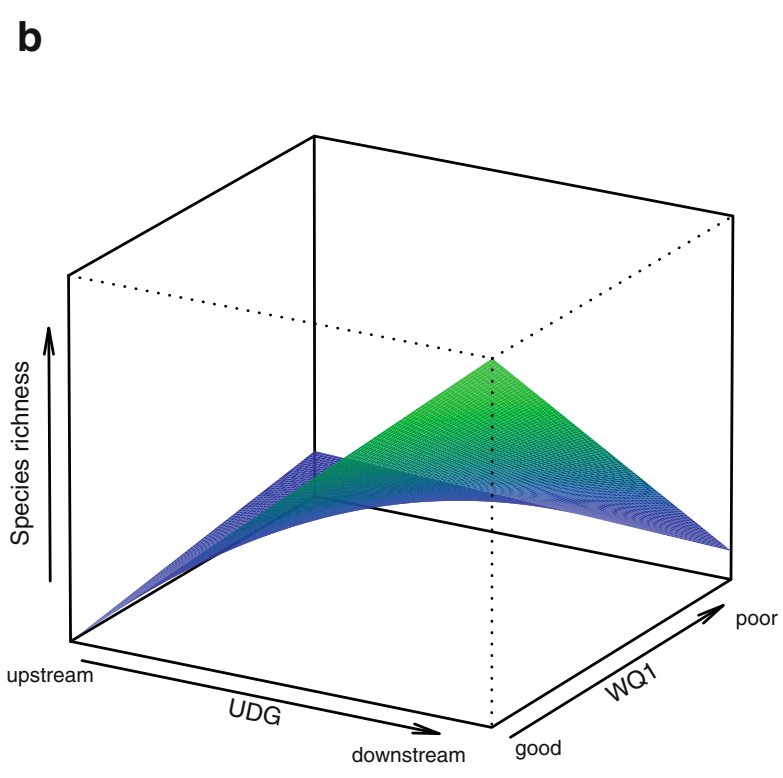

Gag (Gasterosteus gymnurus), Gog (Gobio gobio), Pef(Perca fluviatilis), Pul (Pungitius laevis), Rur (Rutilus rutilus) and Sat (Salmo trutta). b Relationship between species richness, UDG, and WQ1. The generalised linear model included a positive effect of UDG, a negative effect of WQ1 and a negative interaction between UDG and WQ1

increased at the local scale, whereas the reverse pattern was found for sites with high water pollution (WQ1 $>0$ ).

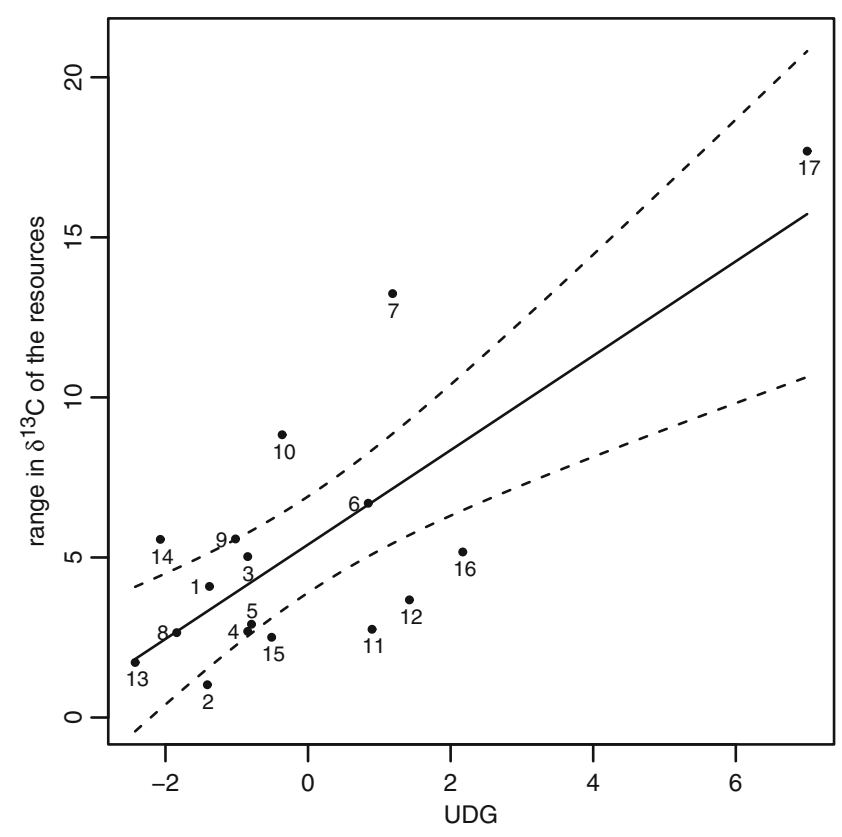

Fig. 7 Relationship between the carbon isotope signal variability among three resources (leaf litter, epilithic biofilm and suspended matter) and UDG. Sites are the numbered points and the linear model is given by the solid line 


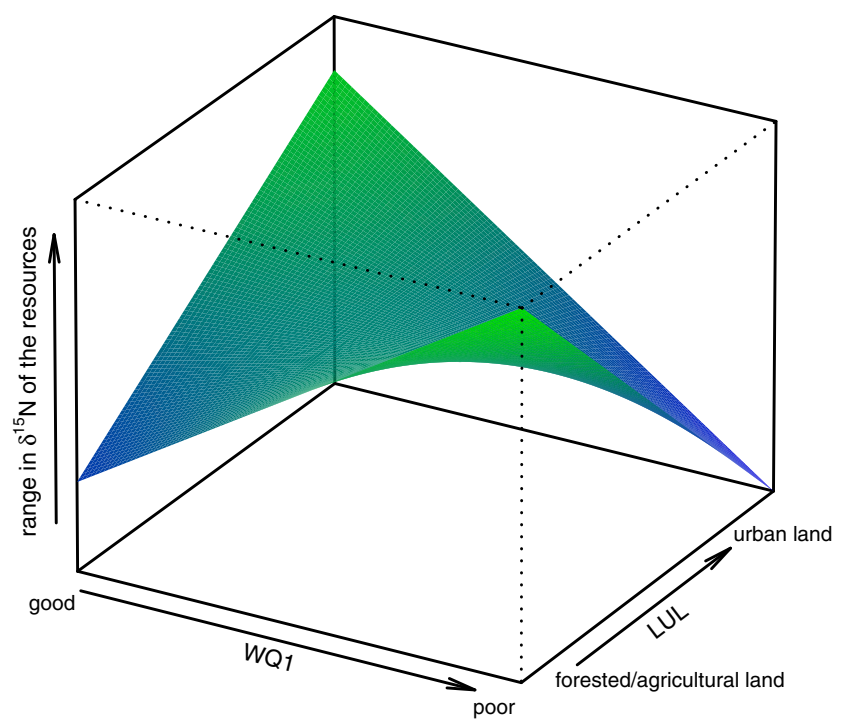

Fig. 8 Modelled relationship between the nitrogen signal variability among three resources (leaf litter, epilithic biofilm, and suspended matter) and LUL and WQ1. The generalised linear model only included a negative interaction between LUL and WQ1

\section{Discussion}

\section{The role of local vs. regional scales}

The medium correlation between land use at local and regional scales suggested that land use in the buffer zone was not strongly linked to land use in the catchment. For instance, the sites 9, 10 and 13 in Fig. 3 displayed similar land use at the regional scale (a mixture of urban and agricultural land), but different land use at the local scale (from a mixture of forested and agricultural land to a dominance of urban land). This indicated that land use at the local scale was also affected by other factors than land use at the regional scale. The correlation between land use at the local scale and water pollution was not surprising as an increase in urbanisation is often associated with an increase in the amount of impervious surfaces (Paul and Meyer 2001) leading to urban runoff and increasing water pollution (Liu et al. 2013). Similarly, the relationship between land use at the regional scale and water quality 2 (WQ2) reflected the relationship between the amount of forested land in the catchment, and the degree of erosion (e.g. Allan et al. 1997).

Beside the effect of upstream-downstream gradient (e.g. Hette-Tronquart et al. 2016) on both biological structure and food web, we found that land use in the buffer zone had a biological impact on streams. The effect of LUL was slightly less important than the effect of UDG, but LUL effect concerned both biological structure (species composition) and food web (trophic diversity and heterogeneity in exploited resources). The effect on species composition was weak, and mainly consisted in a gradient from sensitive ( $C$. gobio) to tolerant species ( $G$. gymnurus) that reflected the increase in urbanisation along LUL. The effect on food web was stronger than the effect on biological structure, and depended on site's position along the upstream-downstream gradient of the river. In headwater streams, urbanisation (increase in LUL) was associated with a very slight increase in trophic diversity (ISA) and heterogeneity in exploited resources $\left(\mathrm{CR}_{\mathrm{adp}}\right)$, whereas at downstream sites, urbanisation was related to a strong decrease in ISA and $\mathrm{CR}_{\mathrm{adp}}$. We assumed that the changing influence of urbanisation from upstream to downstream was related to an effect on the diversity in available resources, and the absence of land-use effect on trophic level richness $\left(\mathrm{NR}_{\mathrm{adp}}\right)$ supported this hypothesis. The idea was that available resources are generally restricted to allochthonous organic matter from riparian vegetation in very small streams (Vannote et al. 1980), and that urbanisation could lift this restriction. First, organic waste inputs due to urbanisation (Liu et al. 2013) could give access to new resources, and increase the diversity in available resources. Secondly, morphological alterations of headwater streams due to urbanisation often consisted in small constructions on the river (e.g. small weirs) that could artificially increase habitat heterogeneity, and thus increase the diversity of available resources. Further downstream, streams are much less limited in resource diversity, and water management induced stronger stream morphological alterations such as channelization (Hladyz et al. 2011). As a result, higher urban land cover in downstream areas could increase omnivorous feeding strategies (due to stress) leading to the decrease in trophic diversity and heterogeneity in exploited resources.

Surprisingly, we did not find any effect of land use at regional scale. Although some previous studies also reported the absence of land use effect at this spatial scale (Crane et al. 2011, Schofield et al. 2008), most studies usually underline the necessity of considering both local and regional scales to describe the biological impact of land use on streams (e.g. Herringshaw et al. 2011, Liess et al. 2012, Maloney and Weller 2011). In our case, however, the results suggest that the local scale may be sufficient to describe how food webs are affected by land use.

\section{The role of fish community structure}

Both upstream-downstream gradient and land use at the local scale affected fish community composition, but this influence remained limited and explained only $16 \%$ of the total inertia of our redundancy analysis. The reasons of this weak effect could be due to (1) the small range of upstream-downstream gradient in our study (e.g. catchment area of the most downstream site smaller than $1000 \mathrm{~km}^{2}$ ) and (2) a process of homogenization of the fish community due to moderate to high anthropogenic pressures on the Orge River catchment (for example our sites were mostly classified as "fair" or "poor" following the Fish-Based Index (FBI), Oberdorff et al. 2002). 
Consequently, changes in species composition could not be the main reason for the observed effects of UDG and LUL on food webs.

By contrast, the effect of UDG was consistently found for both food web (ISA, $\mathrm{CR}_{\mathrm{adp}}$ and $\mathrm{NR}_{\mathrm{adp}}$ ) and species richness, suggesting that species richness was at least partly responsible for UDG effect on food web. The positive relationship between UDG and species richness reflected the well-known increase in species richness from upstream to downstream (e.g. Oberdorff et al. 1993), and was probably due to increasing habitat stability and heterogeneity in downstream areas (Ibañez et al. 2009; Sabo et al. 2010). In addition to UDG effect, species richness was affected by water pollution, but not by land use. Thus, species richness could not play a strong role to explain land-use effect on food web. However, WQ1 effect and LUL effect displayed similar patterns. Like LUL effect, WQ1 effect was changing from upstream to downstream, probably due to changes in the diversity of available resources. The reason was the positive relationship between WQ1 and nutrient concentrations (see Table 1). Higher nutrient concentrations could give access to new resources, lift the limitation in resource diversity (see above) and counterbalance the negative impact of water pollution in headwater streams. Further downstream resource diversity is much less limited, and we assumed that the compensation of nutrient did not take place anymore. As a result, higher water pollution in downstream areas could lead to a decrease in fish species richness, due to the loss of sensitive species.

The analysis of fish community structure showed that land use had a weak effect on biological structure. Thus, fish community structure only played a minor role in the land-use effect on food webs. According to Post and Takimoto (2007), other potential explanations could be of two kinds: (1) changes in feeding interactions within the fish community (e.g. omnivorous feeding strategy) and (2) changes in available resources at the base of the food web.

\section{Available resources exploited by food webs}

Land use can alter the available resources at the base of the food web (e.g. Bergfur 2013, or Lu et al. 2014), but our observations did not show strong support for this hypothesis. The isotope baseline was not related to any of the explanatory variables, indicating that the $\delta^{15} \mathrm{~N}$ signals of primary consumers were similar among the food webs. This was surprising, because anthropogenic sources of $\mathrm{N}$ are known to display enriched $\delta^{15} \mathrm{~N}$ signals (Anderson and Cabana 2005, Moore et al. 2014) that should be reflected in the isotope baseline. A potential explanation could be a relative homogenous distribution of $\mathrm{N}$-anthropogenic sources across the Orge River catchment. The $\delta^{15} \mathrm{~N}$ signals of three sources of organic matter (leaf litter, epilithic biofilm and suspended matter) seemed to confirm this hypothesis, because they were not related to any of the explanatory variables.

We only found that the variability in the $\delta^{15} \mathrm{~N}$ signals among the three sources of organic matter was related to anthropogenic pressures (interaction of water pollution, and land use at local scale). The correlation between the two variables (WQ1 and LUL) made the interpretation difficult, but the absence of the UDG effect demonstrated that the observed variability of the basal resource signals could not explain the increase in trophic level richness from upstream to downstream.

Similarly, the variability in the $\delta^{13} \mathrm{C}$ signals of basal resources could not explain the observed relationships between the food web metrics and the explanatory variables because this variability was only poorly related to UDG (the observed relationship was strongly influenced by only one site (cf. Fig. 7) where we sampled epilithic biofilm on stones and not the prepared tiles, see Online Resource 1).

From these results, we deduced that land use did not modify the nature (isotope signals) of a given resource. Land-use effects on available resources are probably just limited to a change in the amount of the different resources.

\section{Conclusion}

As a preliminary remark, we underline that our results concern a small river catchment. It would now be interesting to consider other sites distributed over a broader spatial scale to examine whether our observations are specific to this catchment, or can apply more generally.

Most previous studies examining potential relationships between land use and stream biocœnosis only consider each land use category separately. Here, we assess land use with a multivariate index (first axis of the principal component analysis of the three main land use categories), showing that this approach could be powerful to examine how land use affects stream biocœnosis.

Using food web metrics as synthetic measures integrating both biological structure and functioning, we observe that land use does have a biological impact on streams, influencing the whole food web, from basal resources to top predators. Surprisingly, only the local spatial scale was decisive. Interestingly, our observations indicate that the effect of land use is complex and varies from upstream to downstream. Thus, land use influence could be confounded if the upstream-downstream background is not taken into account.

Land use affects both biological structure (i.e. community composition) and food webs (i.e. trophic diversity and range in exploited resources). Structural effect remained quite limited, and could not explain a large part of the land-use effects on food webs. Other potential explanations concerned biological 
functioning (changes in feeding interactions) and availability of resources at food web base.

It is also worth noting that none of our water quality variables affects food webs. Although the effect of land use partly integrates the effect of water quality, this suggests that land use at local scale may be a stronger driver of food webs than water quality itself.

Overall, these results underline the buffer zone of the riparian corridor as an important component of water management.

Acknowledgments Grateful acknowledgment is expressed to the HEF team (part of the Hydrosystems and Bioprocesses Research Unit at Irstea, Antony) for assistance in the field and sample preparation. We thank Adrien Rey and the regional natural park "Parc Naturel Régional de la haute vallée de Chevreuse" for advice and participation to field work. Michel Hénin, head of the RGIS department at the "Institut d'Aménagement et d'Urbanisme d'île-de-France", kindly provided the land cover data. This work was partly funded by the Interdisciplinary Research Program on the Seine River Environment (PIREN-Seinehttp://www.sisyphe.upmc.fr/piren/) and by the project 33 of the framework agreement between Irstea and the French National Agency for Water and Aquatic Environments (ONEMA).

\section{References}

Allan J (2004) Landscapes and riverscapes: the influence of land use on stream ecosystems. Annu Rev Ecol Evol S 35:257-284

Allan J, Erickson D, Fay J (1997) The influence of catchment land use on stream integrity across multiple spatial scales. Freshw Biol 37:149 161

Anderson C, Cabana G (2005) $\delta^{15} \mathrm{~N}$ in riverine food webs: effects of $\mathrm{N}$ inputs from agricultural watersheds. Can JFish Aquat Sci 62:333340

Anderson C, Cabana G (2007) Estimating the trophic position of aquatic consumers in river food webs using stable nitrogen isotopes. J N Am Benthol Soc 26:273-285

Argent D, Carline R (2004) Fish assemblage changes in relation to watershed land use disturbance. Aquat Ecosyst Health 7:101-114. doi: 10.1080/14634980490281407

Bentivoglio F, Calizza E, Rossi D, Carlino P, Careddu G, Rossi L, Costantini M (2015) Site-scale isotopic variations along a river course help localize drainage basin influence on river food webs. Hydrobiologia 770:257-272. doi:10.1007/s10750-015-2597-2

Bergfur J (2013) Temporal variation in carbon and nitrogen isotope ratios of aquatic biota in two contrasting boreal streams. Fund Appl Limnol 182:205-218. doi:10.1127/1863-9135/2013/0410

Boecklen WJ, Yarnes CT, Cook BA, James AC (2011) On the use of stable isotopes in trophic ecology. Annu Rev Ecol Evol S 42:411440. doi:10.1146/annurevecolsys-102209-144726

Borcard D, Gillet F, Legendre P (2011) Numerical ecology with R. Use R! Series, Springer,New York.

Bott TL, Newbold JD, Arscott D (2006) Ecosystem metabolism in piedmont streams: reach geomorphology modulates the influence of riparian vegetation. Ecosystems 9:398-421

Chang HY, Wu SH, Shao KT, Kao WY, Maa CJ, Jan RQ, Liu LL, Tzeng CS, Hwang JS, Hsieh HL, Kao SJ, Chen YK, Lin HJ (2012) Longitudinal variation in food sources and their use by aquatic fauna along a subtropical river in Taiwan. Freshw Biol 57:1839-1853. doi: 10.1111/j.1365-2427.2012.02843.x
Crane D, Johengen T, Allan J (2011) Assessment of quantitative food web metrics for investigating the influence of land use on warm water fish diets. Hydrobiologia 664:1-15

di Lascio A, Rossi L, Carlino P, Calizza E, Rossi D, Costantini M (2013) Stable isotope variation in macroinvertebrates indicates anthropogenic disturbance along an urban stretch of the river Tiber (Rome, Italy). Ecol Indic 28:107-114. doi:10.1016/j.ecolind.2012.04.006

Docile T, Rosa D, Figueiró R, Nessimian J (2016) Urbanisation alters the flow of energy through stream food webs. Insect Conserv Diver. doi: 10.1111/icad.12176

Feld C, Birk S, Bradley D, Hering D, Kail J, Marzin A, Melcher A, Nemitz D, Pedersen M, Pletterbauer F, Pont D, Verdonschot P, Friberg N (2011) From natural to degraded rivers and back again. A test of restoration ecology theory and practice. Adv Ecol Res 44: 119-209

Friberg N, Bonada N, Bradley D, Dunbar M, Edwards F, Grey J, Hayes R, Hildrew A, Lamouroux N, Trimmer M, Woodward G (2011) Biomonitoring of human impacts in freshwater ecosystems. The good, the bad and the ugly. Adv Ecol Res 44:1-68

Guilpart A, Roussel J, Aubin J, Caquet T, Marle M, Le Bris H (2012) The use of benthic invertebrate community and water quality analyses to assess ecological consequences of fish farm effluents in rivers. Ecol Indic 23:356-365

Herringshaw C, Stewart T, Thompson J, Anderson P (2011) Land use, stream habitat and benthic invertebrate assemblages in a highly altered Iowa watershed. Am Midl Nat 165:274-293. doi:10.1674/ 0003-0031-165.2.274

Hette-Tronquart N, Mazeas L, Reuilly-Manenti L, Zahm A, Belliard J (2012) Fish fins as non-lethal surrogates for muscle tissues in freshwater food web studies using stable isotopes. Rapid Commun Mass Sp 26:1603-1608. doi:10.1002/rcm.6265

Hette-Tronquart N, Belliard J, Tales E, Oberdorff T (2016) Stable isotopes reveal food web modifications along the upstream-downstream gradient of a temperate stream. Aquat Sci 78:255-265. doi: 10.1007/s00027-015-0421-8

Hladyz S, Åbjörnsson K, Chauvet E, Dobson M, Elosegi A, Ferreira V, Fleituch T, Gessner M, Giller $\mathrm{P}$, Gulis V, Hutton S, Lacoursière J, Lamothe S, Lecerf A, Malmqvist B, McKie B, Nistorescu M, Preda E, Riipinen M, Rîsnoveanu G, Schindler M, Tiegs S, Vought L, Woodward G (2011) Stream ecosystem functioning in an agricultural landscape. The importance of terrestrial-aquatic linkages. Adv Ecol Res 44:211-276

Hynes H (1975) Edgardo Baldi memorial lecture, the stream and its valley. Verhandlungen des Internationalen Verein Limnologie 19: $1-15$

Ibañez C, Belliard J, Hughes R, Irz P, Kamdem-Toham A, Lamouroux N, Tedesco P, Oberdorff T (2009) Convergence of temperate and tropical stream fish assemblages. Ecography 32:658-670. doi:10.1111/j. 1600-0587.2008.05591.x

Jackson A, Inger R, Parnell A, Bearhop S (2011) Comparing isotopic niche widths among and within communities: Siber - Stable Isotope Bayesian Ellipses in R. J Anim Ecol 80:595-602. doi:10. 1111/j.1365-2656.2011.01806.x

Layman C, Arrington D, Montaña C, Post D (2007) Can stable isotope ratios provide for community-wide measures of trophic structure ? Ecology 88:42-48. doi:10.1890/0012-9658(2007)88[42:CSIRPF]2. $0 . \mathrm{CO} ; 2$

Liess A, Le Gros A, Wagenhoff A, Townsend CR, Matthaei CD (2012) Land use intensity in stream catchments affects the benthic food web: consequences for nutrient supply, periphyton C: nutrient ratios, and invertebrate richness and abundance. Freshwater Sci 31:813824

Liu Z, Wang Y, Li Z, Peng J (2013) Impervious surface impact on water quality in the process of rapid urbanization in Shenzhen, China. Environmental Earth Sciences 68:2365-2373. doi:10.1007/ s12665-012-1918-2 
Lu Y, Canuel E, Bauer J, Chambers R (2014) Effects of watershed land use on sources and nutritional value of particulate organic matter in temperate headwater streams. Aquat Sci 76:419-436. doi:10.1007/ s00027-014-0344-9

Maloney K, Weller D (2011) Anthropogenic disturbance and streams: land use and land-use change affect stream ecosystems via multiple pathways. Freshw Biol 56:611-626. doi:10.1111/j.1365-2427.2010. 02522.x

Martínez A, Larrañaga A, Miguélez A, Yvon-Durocher G, Pozo J (2016) Land use change affects macroinvertebrate community size spectrum in streams : the case of Pinus radiata plantations. Freshw Biol 61:69-79. doi:10.1111/fwb.12680

Marzin A, Verdonschot P, Pont D (2013) The relative influence of catchment, riparian corridor, and reach-scale anthropogenic pressures on fish and macroinvertebrate assemblages in French rivers. Hydrobiologia 704:375-388. doi:10.1007/s10750-012-1254-2

Michener R, Lajtha K (2007) Stable isotopes in ecology and environmental science, 2d edn. Blackwell Publishing, Oxford

Middelburg J (2014) Stable isotopes dissect aquatic food webs from the top to the bottom. Biogeosciences 11:2357-2371. doi:10.5194/bg11-2357-2014

Moog D, Whiting P (2002) Climatic and agricultural factors in nutrient exports from two watersheds in Ohio. J Environ Qual 31:72-83

Moore J, Lambert T, Heady W, Honig S, Osterback A, Phillis C, Quiros A, Retford N, Herbst D (2014) Anthropogenic land-use signals propagate through stream food webs in a California, USA, watershed. Limnologica 46:124-130. doi:10.1016/j.limno.2014.01.005

Newsome S, Del Rio C, Bearhop S, Phillips D (2007) A niche for isotopic ecology. Front Ecol Environ 5:429-436. doi:10.1890/15409295(2007)5[429:ANFIE]2.0.CO;2

Oberdorff T, Guilbert E, Lucchetta JC (1993) Patterns of fish species richness in the Seine River basin, France. Hydrobiologia 259:157167. doi:10.1007/BF00006595

Oberdorff T, Pont D, Hugueny B, Porcher JP (2002) Development and validation of a fish-based index (FBI) for the assessment of rivers "health" in France. Freshw Biol 47:1720-1735. doi:10.1046/j.13652427.2002.00884.x

Oksanen J, Blanchet G, Kindt R, Legendre P, Minchin P, O'Hara R, Simpson G, Solymos P, Stevens M, Wagner H (2015) vegan: Community Ecology Package

Paul MJ, Meyer JL (2001) Streams in the urban landscape. Annu Rev Ecol Syst 32:333-365

Petts G, Calow P (eds) (1996) River biota: diversity and dynamics. Blackwell Science, Oxford

Post D, Takimoto G (2007) Proximate structural mechanisms for variation in food-chain length. Oikos 116:775-782. doi:10.1111/j.2007. 0030-1299.15552.x

Pouilly M, Rejas D, Pérez T, Duprey JL, Molina C, Hubas C, Guimarães JR (2013) Trophic structure and mercury biomagnification in tropical fish assemblages, Iténez River, Bolivia. PLoS ONE 8. doi:10. 1371/journal.pone.0065054

Quinn J, Cooper A, Davies-Colley R, Rutherford J, Williamson R (1997) Land use effects on habitat, water quality, periphyton, and benthic invertebrates in Waikato, New Zealand, hill-country streams. New Zeal J Mar Fresh 31:579-597

Rasmussen J, Trudeau V, Morinville G (2009) Estimating the scale of fish feeding movements in rivers using $\delta^{13} \mathrm{C}$ signature gradients. J Anim Ecol 78:674-685. doi:10.1111/j.1365-2656.2008.01511.x

R Core Team (2015) R: a language and environment for statistical computing. R Foundation for Statistical Computing, Vienna

Ruelland D, Billen G, Brunstein D, Garnier J (2007) Seneque : a multiscaling GIS interface to the Riverstrahler model of the biogeochemical functioning of river systems. Sci Total Environ 375:257-273. doi:10.1016/j.scitotenv.2006.12.014

Sabo J, Finlay J, Kennedy T, Post D (2010) The role of discharge variation in scaling of drainage area and food chain length in rivers. Science 330:965-967. doi:10.1126/science.1196005

Scarsbrook M, Quinn J, Halliday J, Morse R (2001) Factors controlling litter input dynamics in streams draining pasture, pine, and native forest catchments. New Zeal J Mar Fresh 35:751-762

Schofield K, Pringle C, Meyer J, Rosi-Marshall E (2008) Functional redundancy of stream macroconsumers despite differences in catchment land use. Freshw Biol 53:2587-2599

Semmens B, Ward E, Moore J, Darimont C (2009) Quantifying inter-and intra-population niche variability using hierarchical bayesian stable isotope mixing models. PLoS One 4. doi:10.1371/journal.pone. 0006187

Sweeney B (1992) Streamside forests and the physical, chemical, and trophic characteristics of piedmont streams in eastern North America. Water Sci Technol 25:2653-2673

Sweeney B, Czapka S (2004) Riparian forest restoration: why each site needs an ecological prescription. Forest Ecolo Manag 192:361-373. doi:10.1016/j.foreco.2004.02.005

Syväranta J, Lensu A, Marjomäki T, Oksanen S, Jones R (2013) An empirical evaluation of the utility of convex hull and standard ellipse areas for assessing population niche widths from stable isotope data. PLoS One 8. doi:10.1371/journal.pone.0056094

Thompson R, Brose U, Dunne J, Hall R, Hladyz S, Kitching R, Martinez N, Rantala H, Romanuk T, Stouffer D, Tylianakis J (2012) Food webs: reconciling the structure and function of biodiversity. Trends Ecol Evol 27:689-697. doi:10.1016/j.tree.2012.08.005

Vander Zanden M, Rasmussen J (1999) Primary consumer $\delta^{13} \mathrm{C}$ and $\delta^{15} \mathrm{~N}$ and the trophic position of aquatic consumers. Ecology 80:13951404

Vannote R, Minshall G, Cummins K, Sedell J, Cushing C (1980) The river continuum concept. Can J Fish Aquat Sci 37:130-137

Werner R, Brand W (2001) Referencing strategies and techniques in stable isotope ratio analysis. Rapid Commun Mass Sp 15:501519. doi: $10.1002 / \mathrm{rcm} .258$

Woodward G, Hildrew A (2002) Food web structure in riverine landscapes. Freshw Biol 47:777-798

Young R, Collier K (2009) Contrasting responses to catchment modification among a range of functional and structural indicators of river ecosystem health. Freshw Biol 54:2155-2170 